\title{
Solanum maternum (Solanaceae), a New Bolivian Relative of the Tree Tomato
}

\author{
Lynn Bohs* and Ann Nelson \\ Department of Biology, University of Utah, Salt Lake City, Utah 84112, U.S.A. \\ *Present address: Department of Botany, Duke University, \\ Durham, North Carolina 27708-0338, U.S.A.
}

Abstract. A new species endemic to Bolivia, Solanum maternum, is described. Solanum maternum belongs to a group of taxa formerly recognized as the genus Cyphomandra. Solanum maternum is morphologically very similar to the tree tomato, Solanum betaceum, and may be its closest wild relative.

The former genus Cyphomandra Sendtner encompasses a group of about 30 species of shrubs and small trees with usually large, pendent fruits. The group is characterized by the presence of an enlarged connective region on the abaxial anther surface; this structure may play a role in pollination by secreting volatile compounds that attract male euglossine bees (Gracie, 1993; Sazima et al., 1993; Soares et al., 1989). Other characteristics of the Cyphomandra group that occur in most, but not all, species include Prévost's architectural model, very large chromosomes, and gametophytic self-incompatibility (Bohs, 1994).

Recent molecular evidence indicates that the Cyphomandra group is nested within Solanum (Bohs \& Olmstead, 1997; Olmstead \& Palmer, 1992, 1997; Spooner et al., 1993), and all Cyphomandra species have now been transferred or returned to Solanum (Bohs, 1995), where the first described species were placed. The infrageneric taxonomy of Solanum is currently under study and no infrageneric rank is consistently used at present for the Cyphomandra group. The monophyly of the Cyphomandra group and the relationship of this group to others within Solanum, particularly its putative sister group, Solanum sect. Cyphomandropsis Bitter, are issues that need to be examined before a taxonomic designation is made.

Species of the Cyphomandra group have been of interest because many produce edible fruits that are gathered from the wild or grown as minor crops. The most important in this regard is Solanum betaceum Cavanilles, the tree tomato, which is frequently cultivated in Latin America and commonly sold in Andean markets. Solanum betaceum has also been an item in international commerce, usually sold under the name "tamarillo." Until recently, little was known about the place of origin of the tree tomato, which is usually regarded as being a cultigen. A group of species from Bolivia has now been identified as the closest wild relatives of $S$. betaceum, based on morphological and crossing data (Bohs, 1991, 1994). The species described here is a new member of this species complex and bears great morphological similarity to $S$. betaceum. Evidence presented below indicates that the new species is interfertile with $S$. betaceum and with two other members of the $S$. betaceum species complex.

Solanum maternum Bohs, sp. nov. TYPE: Bolivia. Santa Cruz: Prov. Caballero, Siberia-El Empalme, $5 \mathrm{~km}$ entrando hacia Khara Huasi, carretera entre Comarapa-Cochabamba, $17^{\circ} 50^{\prime} \mathrm{S}, 64^{\circ} 43^{\prime} \mathrm{W}, 2300 \mathrm{~m}, 8-9$ May 1992 (fl, fr), I. Vargas \& E. Prado 1273 (holotype, NY; isotypes, DUKE, MO not seen, USZ not seen). Figure 1.

Solano betaceo Cavanilles affine, a quo differt corollis albo-purpureis, fructibus maturis luteis, pube paulo sparsiore, connectivis antherarum paulo latioribus.

Small tree or shrub $1-4 \mathrm{~m}$ tall. Branches and petioles moderately to densely puberulent with glandular and eglandular unbranched hairs less than $1 \mathrm{~mm}$ long. Leaf blades simple, unlobed, chartaceous, acuminate at apex, moderately puberulent adaxially, more densely so on veins, densely puberulent abaxially. Trunk leaves with blade ovate, 19-34 cm long, 15-24 cm wide, length:width ratio ca. $1.5: 1$, the base cordate with basal lobes $1-4 \mathrm{~cm}$ long; petioles 11-22 cm long. Crown leaves 4 per sympodial unit, the blade ovate, $6.5-21 \mathrm{~cm}$ long, $5-14 \mathrm{~cm}$ wide, length:width ratio ca. $1-1.5: 1$, the base cordate to auriculate with basal lobes $1-3 \mathrm{~cm}$ long; petioles 2.5-11 cm long. Inflorescence unbranched or branched, ca. 20-60-flowered, 5-10 cm long; peduncle $3-4 \mathrm{~cm}$ long; rachis $2-8 \mathrm{~cm}$ long; pedicels ca. 15-20 mm long, 20-35 mm long in fruit, ca. 1-10 $\mathrm{mm}$ apart, articulated above the 


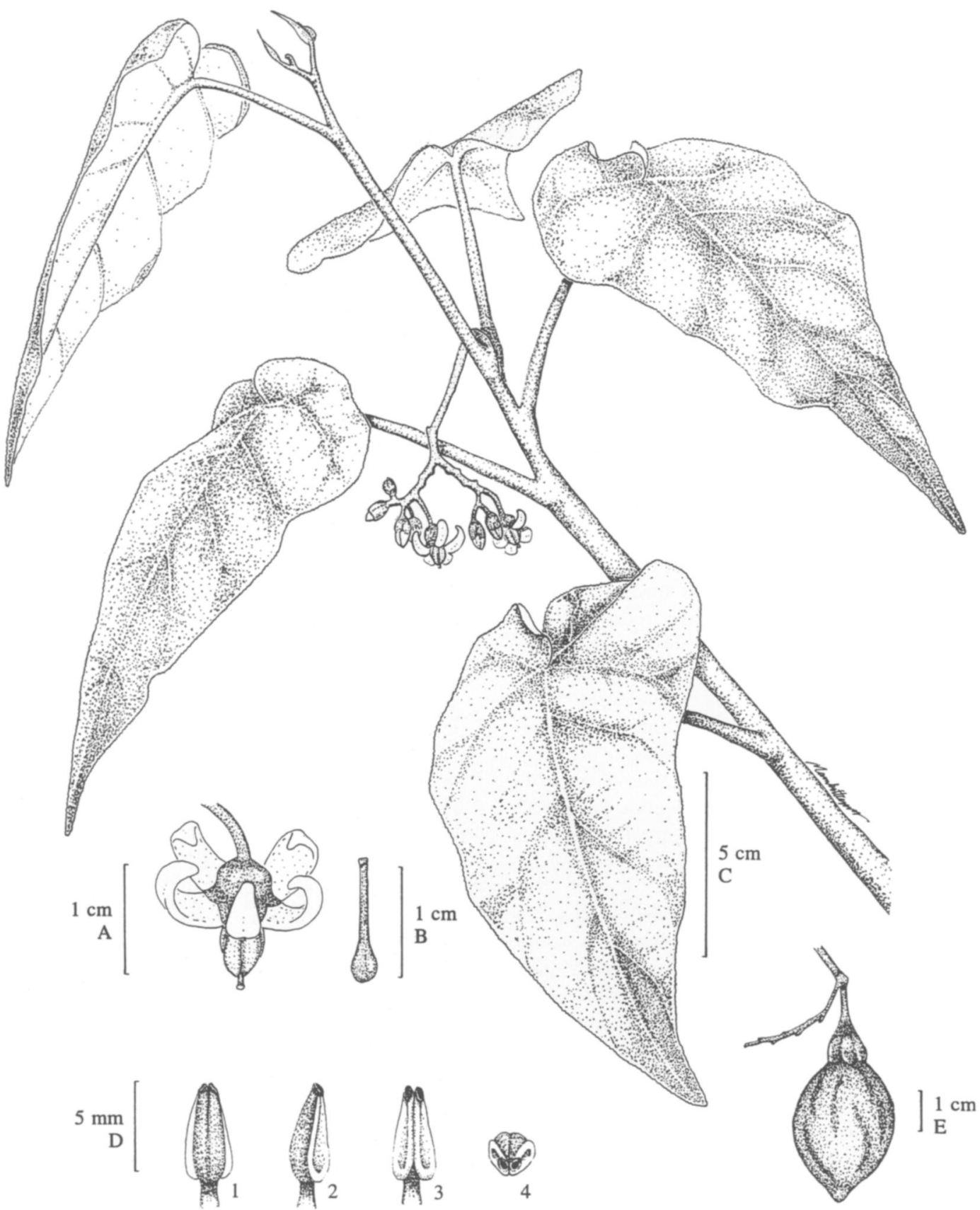

Figure 1. Solanum maternum Bohs. - A. Flower. -B. Gynoecium. - C. Habit. -D. Stamens (left to right, abaxial, side, adaxial, top view). - E. Fruit. All based on living material of I. Vargas \& Prado 1273.

base, leaving pedicellar remnants up to $2 \mathrm{~mm}$ long; peduncle, rachis, and pedicels moderately to densely puberulent with glandular and eglandular unbranched hairs. Flower buds ellipsoidal to ovoid, obtuse to acuminate at apex. Calyx fleshy, sparsely to moderately glandular-puberulent, the radius $6-$ $9 \mathrm{~mm}$, the lobes deltate, somewhat apiculate, ca.
2-3 mm long, 2.5-3 mm wide. Corolla white to pink with a darker pink to purple star toward center, subcoriaceous, stellate, the radius $15-25 \mathrm{~mm}$, the tube $2-4 \mathrm{~mm}$ long, the lobes triangular, 8-12 mm long, 3-5 $\mathrm{mm}$ wide at base, glabrous abaxially and adaxially, the margin tomentose, the apex acute. Anther thecae light yellow to cream, 5-6 mm 
long, 2-3 $\mathrm{mm}$ wide, the pores directed distally; connective lemon yellow to light orange, ca. 4-5 $\mathrm{mm}$ long, 1.5-2 $\mathrm{mm}$ wide, narrowly triangular, abaxially somewhat shorter than the thecae at apex, slightly shorter than them at base, adaxially absent. Ovary glabrous; style cylindrical, glabrous, not dilated distally, 6-8 mm long, $0.5-1 \mathrm{~mm}$ wide, exserted up to $2 \mathrm{~mm}$ beyond anthers; stigma truncate, 0.5-1 mm diam. Fruit ellipsoidal, acute or apiculate at apex, 3-8.5 cm long, 2-5 cm diam., glabrous, yellow to orange when ripe with dark green longitudinal mottling; mesocarp with stone cell aggregates; seeds $3-4 \mathrm{~mm}$ long, $2.5-3 \mathrm{~mm}$ wide, appearing densely pubescent.

Phenology. Flowering specimens have been collected in May, September, October, and December; fruiting specimens have been collected in January, May, June, and December.

Distribution. Cloud forest at 1350-2600 m elevation in Depts. Cochabamba, La Paz, and Santa Cruz, Bolivia.

Local uses and names. Fruits edible. N.v. "pepinillo" (Vargas \& Vargas 710), "pepino del monte" (Nee 38493), "tomate de monte" (Eriksson \& Vargas 3523, 3524, 3525, 3527, Vargas \& Prado 1273), "tomate lima" (Vargas 1460), "tomatillo" (Eriksson \& Vargas 3503).

Etymology. The epithet "maternum" is taken from the Latin for "mother," because of the possibility that this species represents the wild ancestral form of the tree tomato.

Solanum maternum apparently belongs to a complex of closely related taxa from Bolivia, which includes $S$. roseum Bohs [formerly Cyphomandra acuminata Rusby], S. unilobum (Rusby) Bohs [formerly Cyphomandra uniloba Rusby], and S. betaceum [formerly Cyphomandra betacea (Cavanilles) Sendtner], the cultivated tree tomato. Solanum maternum is morphologically very similar to $S$. betaceum, and the two species are difficult to distinguish from herbarium material alone. Differences include slightly longer and less dense pubescence, more shallowly cordate leaves, and slightly wider anther connectives in $S$. maternum. Living material differs from $S$. betaceum in flower and fruit color. Solanum maternum has purplish or pinkish corollas with a deep purple star at base, whereas $S$. betaceum has uniformly white or pinkish corollas. The fruits of $S$. maternum are yellow or light orange, not dark orange or reddish as is typical of $S$. betaceum, although some forms of $S$. betaceum may have yellowish or light orange fruits. Fruits of $S$. maternum usually have a prominent apiculum or "nipple" at the distal end; those of $S$. betaceum may be acute distally, but usually lack an obvious apiculum. The reddish or purplish corollas of $S$. maternum resemble those of $S$. roseum, but the latter species is nearly glabrous and has much larger seeds than $S$. maternum. Solanum maternum differs from $S$. unilobum in its corolla color (S. unilobum has greenish corollas), its unexpanded style and small stigma, and its more abundant pubescence.

Solanum maternum grows wild in upland areas of Bolivia in the Departments of La Paz, Cochabamba, and Santa Cruz. Solanum unilobum also occurs in this area, but is generally found at lower elevations $(300-1700 \mathrm{~m})$. Solanum roseum has been found only farther to the northwest in the Department of $\mathrm{La} \mathrm{Paz}$, and its range is probably not sympatric with that of $S$. maternum. Thus far, definitively wild populations of $S$. betaceum have not been found. Occasional plants may persist around abandoned dwellings or sporadically escape from cultivation, but the only reports of more extensive wild stands of this species are from southern Bolivian and northwestern Argentina (Bohs, 1989; Brücher, 1968, 1977; J. Solomon, pers. comm.; E. Zardini, pers. comm.). Fieldwork is needed to fully document the wild status of these plants.

In addition to morphological similarity, crossing data have indicated a close relationship among $S$. betaceum, S. roseum, and S. unilobum. Previous crossing studies have shown that $S$. betaceum will form fertile hybrids with $S$. roseum and $S$. unilobum (Bohs, 1991), although each of these crossing combinations is successful in only one direction. Crossing data thus suggest that $S$. roseum and $S$. unilobum may have played a role in the origin of the cultivated species, $S$. betaceum. Solanum roseum and $S$. unilobum are self-incompatible, but all plants of $S$. betaceum examined are self-compatible. This is consistent with the observation that cultivated taxa have often evolved self-compatible breeding systems from self-incompatible ancestors (de Nettancourt, 1977; Rick, 1988).

To further understand the placement of $S$. $m a-$ ternum, we collected data on breeding systems and crossability of $S$. maternum with other members of the complex. These data are presented below.

Greenhouse crosses were performed with two accessions each of $S$. maternum, S. betaceum, and $S$. unilobum using the methods described in Bohs (1991). Provenance and voucher data can be found in Table 1. Living material of $S$. roseum was unavailable for the crossing study.

Pollen viability. Pollen viability of the $S$. maternum plants, as measured by staining in aniline blue/lactophenol, was high (91-99\%) throughout the study period, with the exception of one Vargas 
Table 1. Voucher information for plants used in the crossing study.

\begin{tabular}{|c|c|c|}
\hline Species & Collector and locality & $\begin{array}{c}\text { Bohs } \\
\text { voucher number }\end{array}$ \\
\hline \multirow[t]{2}{*}{ S. betaceum } & $\begin{array}{l}\text { Sperling s.n. } \\
\text { Ecuador. Pichincha: Quito, purchased in } \\
\text { La Vincentina market }\end{array}$ & 2274,2275 \\
\hline & $\begin{array}{l}\text { Nee } 30359 \\
\text { Bolivia. Cochabamba: purchased in Co- } \\
\text { chabamba market }\end{array}$ & 2468 \\
\hline \multirow[t]{2}{*}{ S. maternum } & $\begin{array}{l}\text { I. Vargas \& Prado } 1273 \\
\text { Bolivia. Dept. Santa Cruz: zona de San } \\
\text { Juan del Potrero, Los Sagüintales, lado SW } \\
\text { del Parque Nacional Amboró }\end{array}$ & 2694 \\
\hline & $\begin{array}{l}\text { I. Vargas } 1460 \\
\text { Bolivia. Dept. Santa Cruz: Prov. Caballero, } \\
\text { Cerro Bravo }\end{array}$ & 2547 \\
\hline \multirow[t]{2}{*}{ S. unilobum } & $\begin{array}{l}\text { Sperling \& King } 5500 \\
\text { Bolivia. Dept. La Paz: Larecaja, between } \\
\text { Consata and Mapiri }\end{array}$ & 2283,2284 \\
\hline & $\begin{array}{l}\text { Eriksson \& I. Vargas } 3530 \\
\text { Bolivia. Dept. Santa Cruz: cultivated in } \\
\text { Jardín Botánico, Santa Cruz }\end{array}$ & 2549 \\
\hline
\end{tabular}

1460 plant whose pollen stainability was $58 \%$. Pollen stainability of the $S$. betaceum and $S$. unilobum accessions averaged $71 \%$ and $78 \%$, respectively, lower than reported previously (Bohs, 1991).

Intraspecific crosses. No fruits were produced from 120 self-pollinations of both accessions of $S$. maternum. In contrast, $7.2 \%$ of the intraspecific sib crosses yielded fruits. Pollen tube observations were consistent with these results, with good pollen tube growth into the ovaries in sib crosses, but all pollen tube growth inhibited in the style in selfpollinations. These results indicate that the $S$. $m a$ ternum accessions are self-incompatible.

A new accession of $S$. unilobum was examined during this study. Only one plant of this accession flowered during the study period, so sib crosses could not be performed. Unsuccessful pollen tube growth and lack of fruit set following self-pollinations suggest that this accession is self-incompatible.

Interaccession crosses of $S$. maternum were successful in both directions, yielding fruits with many viable seeds that subsequently germinated into $F_{1}$ hybrid plants. Many pollen tubes were seen growing into the ovary and around the ovules in these crossing combinations.

Interspecific crosses. Full-sized fruits were set in all interspecific crossing combinations among $S$. maternum, S. betaceum, and S. unilobum, but fruit set was often low (ca. 4-20\% success). Likewise, pollen tube growth was uniformly successful in all directions. Vigorous $F_{1}$ hybrid plants were produced from the interspecific combinations $S$. $m a$ ternum $(\$) \times S$. betaceum $(\delta), S$. maternum $(\$) \times$ $S$. unilobum (ठ), and $S$. unilobum ( $\$) \times S$. maternum (ठ). Seeds from the $S$. betaceum $(\$) \times S$. maternum $(\delta)$ crosses usually appeared flat and misshapen, and only 3 seeds of this combination germinated from 13 fruits produced.

When these results are considered along with those of Bohs (1991), the following conclusions emerge: (1) the wild members of the complex, $S$. maternum, S. unilobum, and $S$. roseum, are selfincompatible, whereas all accessions of the putative cultigen $S$. betaceum that have been examined are self-compatible, and (2) all species of the complex that have been tested are interfertile to some extent. The high degree of morphological similarity among the taxa on herbarium sheets precludes speculation about the degree of natural hybridization among members of the complex. Additional fieldwork is needed to sort out morphological differences among living plants that are not evident in dried material, and other accessions, particularly of $S$. maternum and $S$. betaceum, should be examined for self-incompatibility. The geographical distributions of the taxa of the complex also need to be documented in detail to determine if plants of these taxa are indeed sympatric and can thus exchange genes in nature.

Accumulating evidence suggests that $S$. maternum, $S$. unilobum, and/or $S$. roseum may have been 
involved in the origin of the tree tomato, $S$. betaceum. Questions that remain concern the status of $S$. betaceum as a cultigen and the exact series of events that have led to its evolution. The close morphological resemblance of $S$. maternum to $S$. betaceum and its self-incompatible breeding system suggests that $S$. maternum may be the wild ancestral form of the tree tomato. However, more field, greenhouse, and laboratory work needs to be done to support this hypothesis. Solanum maternum should be explored as a source of useful genes for improvement of the tree tomato, and may itself be valuable as an economic fruit crop.

Paratypes. BOLIVIA. Cochabamba: Prov. Carrasco, Serranía Siberia, $20-35 \mathrm{~km} \mathrm{~W}$ of Comarapa on the old Cochabamba-Santa Cruz road (Hwy. 4), ca. 2000 m, 1415 Jan. 1990 (fr), Dorr \& Barnett 7038 (MO, NY). La Paz: Prov. Sud Yungas, $7 \mathrm{~km}$ de Huancané en carretera a San Isidro, $16^{\circ} 21^{\prime} \mathrm{S}, 67^{\circ} 31^{\prime} \mathrm{W}, 2300 \mathrm{~m}, 13 \mathrm{Dec} .1989$ (fr), D. N. Smith et al. 13920 (NY). Santa Cruz: Prov. Caballero, Santa Rosa, $17^{\circ} 52^{\prime} \mathrm{S}, 6^{\circ} 12^{\prime} \mathrm{W}, 2100 \mathrm{~m}, 3$ May 1993 (fr), Eriksson \& I. Vargas 3503, 3504 (NY), 5 km NE Río Lapacha, 1900 m, 4 May 1993 (fr), Eriksson \& I. Vargas 3507 (NY), $1800 \mathrm{~m}$, Eriksson \& I. Vargas 3508 (NY); Prov. Caballero, Verdesillo, $17^{\circ} 50^{\prime} \mathrm{S}, 6^{\circ} 33^{\prime} \mathrm{W}, 2400$ m, 10 May 1993 (fr), Eriksson \& I. Vargas 3523, 3524, 3525 (NY); Prov. Caballero, Locotal, $17^{\circ} 45^{\prime} \mathrm{S}, 64^{\circ} 45^{\prime} \mathrm{W}$, 2230 m, 10 May 1993 (fl, fr), Eriksson \& I. Vargas 3527 (NY); Prov. Caballero, Parque Nacional Amboró, Cerro Bravo, cerca Comarapa, 2600 m, 17 June 1995 (fr), Jardim et al. 1987 (MO, NY); Prov. Caballero, entre 15 y 25 $\mathrm{km}$ al $\mathrm{N}$ de San Juan de Potrero, hacia Cerro Bravo, $17^{\circ} 48^{\prime} \mathrm{S}, 64^{\circ} 15^{\prime} \mathrm{W}, 2000-2500$ m, 6 June 1992 (fr), Killeen \& I. Vargas 4068 (MO, NY), 4112 (MO, NY); Prov. Florida, $5 \mathrm{~km} \mathrm{SW}$ of Yerba Buena, top of ridge at upper reaches of Quebrada Agua Blanca, $18^{\circ} 01^{\prime} \mathrm{S}, 64^{\circ} 03^{\prime} \mathrm{W}$, 1900-1950 m, 23 Dec. 1989 (f), Nee \& I. Vargas 38287 (NY); Prov. Vallegrande, SW side of Los Sitanos and along Quebrada Seca, $18^{\circ} 52^{\prime} \mathrm{S}, 63^{\circ} 57^{\prime} 30^{\prime \prime} \mathrm{W}, 1350 \mathrm{~m}, 27$ Dec. 1989 (fl, fr), Nee 38493 (NY); Prov. Florida, 7 km (by air) $\mathrm{NE}$ of Mairana, on dirt road NE of "Yungas," $18^{\circ} 05^{\prime} \mathrm{S}$, $63^{\circ} 55^{\prime} \mathrm{W}, 2100$ m, 2 June 1991 (fr), Nee 40694 (NY); Prov. Vallegrande, Alto Seco, 21 km SE (línea recta) de Pucará, $18^{\circ} 53^{\prime} \mathrm{S}, 64^{\circ} 05^{\prime} \mathrm{W}, 2163 \mathrm{~m}, 13$ May 1988 (fl, fr), Saldias 351 (NY); Prov. Caballero, $50 \mathrm{~km}$ al N de Mataral (en la carretera Santa Cruz-Comarapa) pasando por San Juan del Potrero y bajando a la cuenca del alto Río Ichilo, 2000 2100 m, 26 May 1989 (fl, fr), Quintana \& Garcta 13429 (NY); Prov. Vallegrande, La Centinela y Tupiriqui (La Yunga), $15 \mathrm{~km}$ SE linea recta de Piraimirí, $18^{\circ} 40^{\prime} \mathrm{S}$, $63^{\circ} 48^{\prime} \mathrm{W}, 1500 \mathrm{~m}, 3$ Sep. 1990 (f), I. Vargas \& E. Vargas 710 (NY); zona de San Juan del Potrero, Los Sagüintales, lado SW del Parque Amboró, I. Vargas 1322 (NY, USZ); Prov. Caballero, Cerro Bravo, ca. 2000 m, 10 June 1992, I. Vargas 1460 (NY, USZ); Prov. Florida, Parque Nacional Amboro, La Yunga, trayecto entre Chape y el Corral, 8$10 \mathrm{~km}$ al NE de Mairana, senda de la Yunga hacia el Río San Rafael, $18^{\circ} 04^{\prime} \mathrm{S}, 63^{\circ} 53^{\prime} \mathrm{W}, 2300 \mathrm{~m}, 23$ May 1993 (fr), I. Vargas et al. 2513 (NY); Prov. Caballero, Parque Nacional Amboró, proximidades del Cerro Bravo a $10 \mathrm{~km}$ al $\mathrm{N}$ de Comarapa, alrededores de la Parcela permanente, $17^{\circ} 49.5^{\prime} \mathrm{S}, 64^{\circ} 32.5^{\prime} \mathrm{W}, 2400-2600$ m, 18-25 Oct. 1993 (f), I. Vargas \& Jardim 2947 (NY); Prov. Vallegrande, Monte Paulo, 4-5 km SE de Piraymirí sobre la carretera a Mascicurí, $18^{\circ} 39.4^{\prime} \mathrm{S}, 63^{\circ} 56^{\prime} \mathrm{W}, 2160$ m, 27 Dec. 1994 (f), I. Vargas \& V. Vargas 3688 (NY).

Acknowledgments. We gratefully acknowledge the help of Israel Vargas of USZ, Santa Cruz, Bolivia, who first sent us seeds of $S$. maternum, and of Michael Nee of the New York Botanical Garden who has been a constant source of information and support. We also thank Marlene Lambert-Tempest for the illustration, the curators at NY and MO for specimen loans, and the greenhouse staff at the University of Utah Department of Biology for maintaining living collections.

\section{Literature Cited}

Bohs, L. 1989. Ethnobotany of the genus Cyphomandra (Solanaceae). Econ. Bot. 43: 143-163.

1991. Crossing studies in Cyphomandra (Solanaceae) and their systematic and evolutionary significance. Amer. J. Bot. 78: 1683-1693.

- 1994. Cyphomandra (Solanaceae). Flora Neotropica Monograph 63. New York Botanical Garden, Bronx, New York.

1995. Transfer of Cyphomandra (Solanaceae) and its species to Solanum. Taxon 44: 583-587.

— \& R. G. Olmstead. 1997. Phylogenetic relationships in Solanum (Solanaceae) based on $n d h \mathrm{~F}$ sequences. Syst. Bot. 22: 5-17.

Brücher, H. 1968. Die genetischen Reserven Südamerikas für die Kulturpflanzenzuchtung. Theor. Appl. Genet. 38: 9-22.

Berlin

Gracie, C. 1993. Pollination of Cyphomandra endopogon var. endopogon (Solanaceae) by Eufriesea spp. (Euglossini) in French Guiana. Brittonia 45: 39-46.

Nettancourt, D. de. 1977. Incompatibility in Angiosperms. Springer-Verlag, Berlin.

Olmstead, R. G. \& J. D. Palmer. 1992. A chloroplast DNA phylogeny of the Solanaceae: Subfamilial relationships and character evolution. Ann. Missouri Bot. Gard. 79: 346-360.

- $\&$ 1997. Implications for the phylogeny, classification, and biogeography of Solanum from cpDNA restriction site variation. Syst. Bot. 22: 19-29.

Rick, C. M. 1988. Evolution of mating systems in cultivated plants. Pp. 133-147 in L. D. Gottlieb \& S. K. Jain (editors), Plant Evolutionary Biology. Chapman \& Hall, London.

Sazima, M., S. Vogel, A. Cocucci \& G. Hausner. 1993. The perfume flowers of Cyphomandra (Solanaceae): Pollination by euglossine bees, bellows mechanism, osmophores, and volatiles. Pl. Syst. Evol. 187: 51-88.

Soares, A. A., L. A. de O. Campos, M. F. Vieira \& G. A. R. de Melo. 1989. Relações entre Euglossa (Euglossella) mandibularis Friese, 1899 (Hymenoptera, Apidae, Euglossini) e Cyphomandra calycina (Solanaceae). Ci. \& Cult. 41: 903-905.

Spooner, D. M., G. J. Anderson \& R. K. Jansen. 1993. Chloroplast DNA evidence for the interrelationships of tomatoes, potatoes, and pepinos (Solanaceae). Amer. J. Bot. 80: 676-688. 